\title{
Correlation of Virulence Determinants of Staphylococcus aureus to the Severity of Diabetic Foot Ulcers in a Tertiary Care Centre, Egypt
}

\author{
Yasmin Nabiel $^{1^{*}}$ and Ghada Barakat ${ }^{1}$ \\ ${ }^{1}$ Department of Medical Microbiology and Immunology, Faculty of Medicine, The Mansoura University, \\ El-Gomhouria Street, Mansoura, Egypt.
}

Authors' contributions

This work was carried out in collaboration between both authors. Author YN designed the idea of the research and was responsible for the processing of samples obtained from the included cases, writing

of the manuscript, evaluating the results and submitting the manuscript for publishing. Author GB shared in processing of samples and writing of the manuscript. Both authors read and approved the final manuscript.

Article Information

DOI: $10.9734 / \mathrm{MRJI} / 2017 / 34789$

Editor(s):

(1) Xing Li, Division of Biomedical Statistics and Informatics, Department of Health Sciences Research, Mayo Clinic College of

Medicine, USA.

Reviewers:

(1) R. Nagamani, NTR University of Health, India.

(2) Prasanta Kumar Maiti, Institute of Post Graduate Medical Education \& Research, Kolkata, India. Complete Peer review History: http://www.sciencedomain.org/review-history/19958

Original Research Article

Received $12^{\text {th }}$ June 2017

Accepted $3^{\text {rd }}$ July 2017

Published $8^{\text {th }}$ July 2017

\section{ABSTRACT}

Aim: This study aimed to estimate the correlation of the Staphylococcus aureus virulence determinants to the severity of the diabetic foot ulcers in patients admitted to diabetic foot Unit at Mansoura University Hospitals.

Study Design: A prospective study was performed.

Place of Study and Duration: This study was performed in diabetic foot Unit of Mansoura University hospital, Egypt.

Methodology: The study included 95 patients clinically diagnosed with diabetic foot ulcers from whom swabs were obtained from the foot lesions to be processed followed by detecting virulence determinants in isolated $S$. aureus by PCR.

Results: Staphylococcus aureus was isolated from 34 cases (35.8\%). icaA, icaD, pvl and tst genes were detected in $61.8 \%, 67.6 \%, 53 \%$, and $32.4 \%$ of $S$. aureus isolates respectively with higher 
prevalence in isolated strains from more severe infections and results were stastically significant. coa and clfA genes were positive $97.1 \%$ and $94.1 \%$ isolates respectively.

Conclusion: The results showed that the $S$. aureus strains causing infections in diabetic foot patients having genes: ica $A$, ica $D, p v l$ and tst may be correlated to the severity of lesions whereas coa and clfA were not.

Keywords: Diabetic foot; icaA; icaD; pvl; tst; coa; clfA; Polymerase chain reaction.

\section{ABBREVIATIONS}

PCR: Polymerase Chain Reaction

Staphylococcus aureus: $S$. aureus

\section{INTRODUCTION}

Lots of studies consider infections in diabetic foot as a great clinical and financial problem to the patients suffering from diabetes [1,2,3] proved by being one of the disastrous complications that commonly proceed throughout the course of the disease up to septic gangrene which may end in amputation of the foot in up to $70 \%$ of diabetic patients especially if uncontrolled ${ }^{2}$. Studying the types of organisms causing diabetic foot infections showed a great diversity, from one patient to another, and also from one locality to another [4].

The polymicrobial nature of infected diabetic foot shown clearly through microbiological studies have demonstrated that, the most commonly detected aerobic isolates include coagulasepositive Staphylococcus spp, besides other coagulase-negative ones, Enterococcus spp., in addition to various types of Gram negative bacteria [3]. The most commonly reported anaerobic causative agents include Clostridium spp., Peptostreptococcus spp, and Bacteroides fragilis [5].

Staphylococcus aureus is one of commensal bacteria over skin and mucosa that may be a cause of lots of infections in human beings including diabetic patients, these infections may range from minor skin infections to severe infections that can end in septicaemia and osteomyelitis [6].

We can attribute the pathological effects of $S$. aureus to a variety of virulence factors including biofilm formation aiming to help the bacterium to evade the immune system and to resist to antibiotic therapies through the formation of adherent bacterial populations that grow inside a polymeric structure [7]. The biosynthesis of polysaccharide intercellular adhesion molecules in which bacteria is entrapped producing the biofilm, is attributed to several virulence genes like icaA and $i c a D$.

Staphylococci, especially S. aureus produce other virulence factors like toxins, immune evasion factors and tissue degrading enzymes [8]. They produce coagulase enzyme that is encoded by coa gene and clumping factor which is encoded by clfa gene, it hinders phagocytosis and binds to fibrinogen changing it into fibrin leading to platelet activation [9].

Another virulence determinant is cytotoxin panton-valentine leukocidin ( $p v l)$, which is considered a major hazard causing severe necrosis in tissues. Its encoding gene locus is determined to be carried on a bacteriophage [10]. Its disastrous effect is produced through causing leukocyte destruction and tissue necrosis. Fewer than $5 \%$ of $S$. aureus strains can produce it [10]. Some isolates also secrete the toxic shock syndrome toxin 1 (TSST-1). It is a superantigen toxin encoded by the tst gene, scarlet fever and toxic shock syndrome caused by $S$. aureus strains are attributed to such type of toxin $[11,12]$.

Main diagnostic methods of such wound infections are based mainly on clinical laboratory investigations supporting the isolation of the bacterial cause by culturing techniques [13]. This can be only fulfilled through obtaining the proper sample by swabbing techniques versus tissue sampling of infected diabetic foot ulcers [14].

To the best of our knowledge, finding the correlation between the presence or absence of various virulence factors and the grading of the diabetic foot ulcers was not yet studied in our locality.

In our study, we aimed to find a correlation between the $S$. aureus virulence determinants and the severity of the diabetic foot ulcers in patients admitted to diabetic foot Unit at Mansoura University Hospitals. 


\section{MATERIALS AND METHODS}

\subsection{Selection of Patients}

This study was carried out in Medical Microbiology and Immunology department of Mansoura faculty of Medicine over a period beginning in October 2015 and terminating in December 2016. Ninety five patients clinically diagnosed with diabetic foot ulcers were enrolled in this study. The grading of foot ulcers was done following Wagner's classification [15] as follows (grade 0- showed hyperkeratosis; grade I showed superficial ulcers; grade- II suffered from deep ulcers; grade- III showed tendonitis, osteomyelitis, cellulites, and or abscess; gradeIV presented by ulcers with gangrene of a toe or forefoot; and finally grade $-\mathrm{V}$ had massive gangrene of the whole foot. The study protocol was reviewed and accepted by our faculty's research board with a written informed consent from all included subjects.

\subsection{Collection of Samples}

A sterile cotton-tipped swab was used to obtain a superficial swab from the center of ulcer after cleaning the foot lesion with sterile saline. All obtained samples were transported to Medical Microbiology and Immunology Department for further processing. They were used for detecting bacterial causes of infection through different culturing techniques.

\subsection{Isolation and Identification of Aerobic Bacterial Causes}

Once samples were obtained, they were directly inoculated onto appropriate culturing media to be incubated aerobically at $37^{\circ} \mathrm{C}$ for 24 hs. Identification of different isolates was done by resulting colonies' morphological characters, Gram staining characters and suitable indicated biochemical reactions [16].

\subsection{Identification of Staphylococcus aureus}

Staphylococci were chronologically identified by their characteristic colony morphology including the produced pattern of haemolysis, Gram staining criteria, biochemical reactions such as catalase and coagulase activity testing, DNase test, and mannitol fermentation on mannitol salt agar. Results were confirmed by API Staph 32 (bioMe' rieux, Marcy-l'E' toile, France). Tests were carried out and interpreted according to the manufacturers' guidelines.

\subsection{Screening for Virulence Factors in Staphylococcus aureus Isolates}

Isolated $S$. aureus strains were subcultured on brain heart infusion agar to be subjected to a process of genomic DNA extraction using QIAamp DNA Extraction Kit (QIAGEN Hilden, Germany) then PCR amplification of studied genes.

- ica $\boldsymbol{A}$ and ica $\boldsymbol{D}$ genes: The set of primers used to amplify icaA gene was $5^{\prime}$ TCTCTTGCAGGAGCAATCAA-3' \& 5'TCAGGCACTAACATCCAGCA-3' to give a DNA fragment of 188-bps, and that for icaD was 5'ATGGTCAAGCCCAGACAGAG-3' \& 5'CGTGTTTTCAACATTTAATGCAA-3' giving a DNA fragment of 198-bps [17].

The reaction was carried out through a multiplex PCR in a $25-\mu$ l volume containing $1 \mu \mathrm{M}$ of each primer with $150 \mathrm{ng}$ of the extracted DNA, $100 \mu \mathrm{M}$ of each neucleotide, $1 \mathrm{U}$ of Taq DNA polymerase, and buffer. We applied the following conditions for the amplification process using (Norwall, CT, USA) thermal cycler, 5 mins of initial denaturation at a temperature of $94^{\circ} \mathrm{C}$ for, then 50 cycles at $94^{\circ} \mathrm{C}$ for $30 \mathrm{~s}$ for denaturation, annealing at $55.5^{\circ} \mathrm{C}$ for $30 \mathrm{~s}$, extension at $72^{\circ} \mathrm{C}$ for $30 \mathrm{~s}$, and finally elongation for $1 \mathrm{~min}$ at $72^{\circ} \mathrm{C}$ [17].

- coa gene: We used the following set of primers for amplification: coa-1 5'-ATA GAG ATG CTG GTA CAG G-3' and coa-2 5'-GCT TCC GAT TGT TCG ATG C-3' yielding a DNA fragment of $350-b p s$. The conditions used were: $94^{\circ} \mathrm{C}$ for 5 min for initial denaturation, then 30 successive cycles as follows $94^{\circ} \mathrm{C}, 1 \mathrm{~min} ; 58^{\circ} \mathrm{C}, 1 \mathrm{~min}$; $72^{\circ} \mathrm{C}, 1 \mathrm{~min}$ [18].

- clfA gene: The set of primers used was clfA-1 5'- GGC TTC AGT GCT TGT AGG -3 ' and clfA-2 5'- TTT TCA GGG TCA ATA TAA GC -3 ' for obtaining a DNA fragment of 540-bps. Initial denaturation was done for $5 \mathrm{~min}$ at $94^{\circ} \mathrm{C}$ and then 35 following cycles at $94^{\circ} \mathrm{C}$ for $1 \mathrm{~min} ; 57^{\circ} \mathrm{C}$ for $1 \mathrm{~min} ; 72^{\circ} \mathrm{C}$ for $1 \mathrm{~min}$ [18].

- pvl gene: We used the following set of primers for amplification: lukS-PV-5'ATCATTAGGTAAAATGTCTGGACATGAT 
CCA-3' and lukF-PV 5'-GCATCAASTGTATTGGATAGCAAAAGC-3' to yield a DNA fragment of 433-bps. The amplification conditions used were 30 successive cycles: $30 \mathrm{~s}$ for denaturation at $94^{\circ} \mathrm{C}, 30 \mathrm{~s}$ for annealing at $55^{\circ} \mathrm{C}$, and then $1 \mathrm{~min}$ for extension at $72^{\circ} \mathrm{C}$ [19].

- tst gene: The set of primers was TST-1 5'TTCACTATTTGTAAAAGTGTCAGACCCA CT-3' and TST-2 5'TACTAATGAATTTTTTTATCGTAAGCCC TT-3' to yield a DNA fragment of 740-bps. The conditions of the reaction were: denaturation, annealing, and extension for $1 \mathrm{~min}$ at $94^{\circ} \mathrm{C}, 1 \mathrm{~min}$ at $55^{\circ} \mathrm{C}$ and $1 \mathrm{~min}$ at $72^{\circ} \mathrm{C}$ respectively [20].

\subsection{Statistical Analysis}

We presented the data as numbers and percentage. We used SPSS software 17 to analyse data by the Pearson's Chi square and 1sample K-S tests. Significance is considered when $P$ value is less than 0.05 .

\section{RESULTS}

We conducted this work in the department of Medical Microbiology and Immunology in Mansoura faculty of Medicine over a period beginning in October 2015 and terminating in December 2016. Ninety five patients clinically diagnosed with diabetes mellitus complicated by diabetic foot ulcers were included in the study. The mean of the studied cases age range was $43 \pm 6.51$ years and their body mass index showed a mean of $21.73 \pm 3.96$. According to Wagner's classification [15], 29 patients were classified as grade I with superficial ulcers, 34 patients were grade- II complaining of deep ulcers, 25 ones grade- III with abscess and only 7 patients were grade- IV having ulcers with gangrene of one toe or forefoot but none were diagnosed as grade zero or grade- $V$ with severe gangrene of the foot as a whole.

Gram positive organisms were isolated from 52 cases $(54.7 \%)$ whereas gram negative isolates were obtained from the remaining 43 ones (45.3\%). Staphylococcus aureus was isolated from 34 cases $(35.8 \%)$, Staphylococcus epidermidis from 10 cases $(10.5 \%)$ whereas Enterococci were detected in 8 cases $(8.4 \%)$. Klebsiella spp.were isolated from 4 cases $(4.3 \%)$, Pseudomonas spp. from 15 patients (15.8\%), Escherichia coli from 18 ones (18.9\%) and finally Proteus spp. were found in 6 samples $(6.3 \%)$, Table 1.
Table 1. Organisms isolated from infected diabetic ulcers

\begin{tabular}{lll}
\hline Isolated organism & № (Total 95) & $\%$ \\
\hline $\begin{array}{l}\text { Gram positive } \\
\text { isolates }\end{array}$ & 52 & 54.7 \\
$\begin{array}{l}\text { Staphylococcus } \\
\text { aureus }\end{array}$ & 34 & 35.8 \\
$\begin{array}{l}\text { Staphylococcus } \\
\text { epidermidis }\end{array}$ & 10 & 10.5 \\
$\begin{array}{l}\text { Enterococci } \\
\text { Gram negative }\end{array}$ & 8 & 8.4 \\
$\begin{array}{l}\text { isolates } \\
\text { Klebsiella spp. }\end{array}$ & 43 & 45.3 \\
$\begin{array}{l}\text { Pseudomonas spp. } \\
\text { Escherichia coli }\end{array}$ & 15 & 4.3 \\
Proteus spp. & 18 & 15.8 \\
\hline
\end{tabular}

icaA gene was positive in $18 \mathrm{~S}$. aureus isolates $(52.9 \%)$ with higher prevalence in grade III and IV diabetic foot cases than grade I and grade II ones, similarly icaD gene was positive in 23 isolates $(67.6 \%)$ showing also higher association with increased severity of the disease, $P$ value was $0.026^{*}$ and $0.037^{*}$ respectively, Table 2.

coa and clfA genes were positive in 33 (97.1\%) and $32(94.1 \%)$ isolates respectively with nearly similar prevalence in all studied grades of diabetic foot infections, $P$ value was 0.59 and 0.71 respectively. pvl gene was demonstrated in $18(53 \%)$ isolates, tst gene was found in $11(32.4 \%)$ ones and both were mainly manifested in more severe infections in grades III and IV, P value was $<0.0001^{*}$ for both, Table 2.

\section{DISCUSSION}

The study carried out by Richard et al. [21] mentioned that Staphylococcus aureus was found to be the most prevalent pathogen that was isolated from diabetic foot ulcers. In spite of being a common inhabitant of humans' skin flora, that may also colonize the nasal cavities in addition to other human mucosa, $S$. aureus is considered as an opportunistic microorganism [22].

By studying different $S$. aureus strains isolated from diabetic foot ulcer: two different populations could be described which were: strains obtained from ulcers showing no evidence of severe infections and showing a low virulence potential in contrast to strains obtained from infected ulcers and having a higher virulence 
Table 2. Results of polymerase chain reaction (PCR) in diabetic foot cases

\begin{tabular}{|c|c|c|c|c|c|c|c|c|c|c|c|}
\hline & \multicolumn{8}{|c|}{ PCR } & \multirow{2}{*}{\multicolumn{2}{|c|}{$\begin{array}{l}\text { Total } \\
\text { (34 cases) }\end{array}$}} & \multirow{3}{*}{$\begin{array}{l}\text { Significance } \\
P \text { value }\end{array}$} \\
\hline & \multicolumn{2}{|c|}{$\begin{array}{l}\text { Grade I } \\
\text { (9 cases) }\end{array}$} & \multicolumn{2}{|c|}{$\begin{array}{l}\text { Grade II } \\
\text { (12 cases) }\end{array}$} & \multicolumn{2}{|c|}{$\begin{array}{l}\text { Grade III } \\
\text { (6 cases) }\end{array}$} & \multicolumn{2}{|c|}{$\begin{array}{l}\text { Grade VI } \\
\text { (7 cases) }\end{array}$} & & & \\
\hline & +ve & -ve & +ve & -ve & +ve & -ve & +ve & -ve & +ve & -ve & \\
\hline ica $A$ gene & 2 & 7 & 5 & 7 & 5 & 1 & 6 & 1 & 18 & 16 & $0.026^{*}$ \\
\hline ica $D$ gene & 3 & 6 & 9 & 3 & 4 & 2 & 7 & 0 & 23 & 11 & $0.037^{*}$ \\
\hline coa gene & 9 & 0 & 11 & 1 & 6 & 0 & 7 & 0 & 33 & 1 & 0.59 \\
\hline clfA gene & 8 & 1 & 11 & 1 & 6 & 0 & 7 & 0 & 32 & 2 & 0.71 \\
\hline$p v l$ gene & 0 & 9 & 5 & 7 & 6 & 0 & 7 & 0 & 18 & 16 & $<0.0001^{*}$ \\
\hline tst gene & 0 & 9 & 1 & 11 & 4 & 2 & 6 & 1 & 11 & 23 & $<0.0001^{*}$ \\
\hline
\end{tabular}

potential [23]. Wagner et al. [15] grading was used for studying the severity of the diabetic foot ulcers in correlation to the $S$. aureus virulence determinants.

Out of the 95 patients with diabetic foot ulcers, 29 patients were classified as grade I with superficial ulcers, 34 patients were grade- II with deep ulcers, 25 ones grade- III with abscess and only 7 patients were grade- IV having ulcers with gangrene of one toe or foot but none were diagnosed as grade zero or grade- $V$ with severe gangrene.

Gram positive organisms were isolated from 52 cases $(54.7 \%)$ whereas Gram negative isolates were obtained from the remaining 43 ones (45.3\%). In a study done in Morocco over 3 years, the bacteria isolated from infected diabetic foot were Gram negative bacilli, Gram positive bacilli and Gram positive cocci in a percentage of $48.8 \%, 6.2 \%$ and $45 \%$ respectively [24].

The severity and outcomes of infected diabetic foot may be also influenced by the polymicrobial status of some cases besides the control measures applied for diabetes and infection.

In this study $S$. aureus was isolated from 34 cases (35.8\%). Staphylococci, in addition to being the most frequently isolated organisms, are attributed to be the most virulent ones in diabetic foot infections [25,26,27]. Gardner et al. [28] showed that the culture results had higher relative abundance of Staphylococcus (46\%). Previous studies done in France demonstrated a correlation between certain virulence genotypes in $S$. aureus isolates from diabetic foot ulcers and the ulcer prognosis [29,22,30]. Belefquih et al. [24] isolated $S$. aureus as the most predominent bacteria $(12.6 \%)$ regardless of the sampling method.
According to the virulence genes, Sotto et al. [29] tried to establish a differentiation between colonized wounds and infected ones in foot ulcers that were culture-positive for only $S$. aureus. Virulence genes were not found in $92 \%$ clinically uninfected ulcers, but present in $98 \%$ infected ulcers.

Important adhesion virulence factors are icaA and ica $D$ genes. icaA gene was positive in $21 \mathrm{~S}$. aureus isolates $(61.8 \%)$ with higher prevalence in grade III and IV diabetic foot cases than grade I and grade II ones. As regard icaD gene, it was positive in 23 isolates $(67.6 \%)$ showing also higher association with increased grading of the disease and the results were stastically significant. In a previous study by Mottola et al. [31], all the $S$. aureus was positive for biofilm associated ica $A$ and icaD genes. The pattern of biofilm growth may play an essential role in chronicity of wounds [32]; it can cause resistance even to higher concentrations of antibiotic than the ones usually needed to kill planktonic cells [33].

coa and clfA genes were positive in 33 (97.1\%) and $32(94.1 \%)$ isolates respectively with nearly similar prevalence in all studied grades of diabetic foot infections. Mottola et al. [34] found that all isolates were coa positive but only $70 \%$ were clfA positive.

pvl gene was found in $18(53 \%)$ isolates, and tst gene in $11(32.4 \%)$. Both were mainly manifested in more severe infections in grades III and IV and the results were stastically significant. tst gene was detected in only one isolate from diabetic foot ulcer (2.4\%) in Mottola et al. study [34].

In a study done on samples from both major abscess and diabetic foot infection in order to determine the presence of $p v l$ gene by realtime $\mathrm{PCR}$, the majority of $S$. aureus real-time 
PCR-positive major abscess samples were at the same instance pvl real-time PCR-positive (89\%). In contrast, a minority of $S$. aureus real-time PCR-positive diabetic foot infection samples were giving $p v l$ real-time PCR-positive results (14\%). In both groups of major abscesses and diabetic foot infections, two samples were pvl real-time PCR positive but not $S$. aureus realtime PCR-positive [35]. Only fourteen percent of the diabetic foot infections were $p v l$ positive.

PVL functions as a bicomponent pore-forming toxin. It is encoded by the lukS-PV and lukF-PV genes, and can induce damage of leukocytes [36]. A previous meta-analysis confirmed that there was an association between PVL and $S$. aureus skin infections, and that was not shown in invasive infections caused by $S$. aureus [37] All the $S$. aureus strains isolated by Mottola et al. [34] from diabetic foot ulcers were negative for pvl gene.

\section{CONCLUSION}

There is a positive correlation between the presence of certain virulence genes of the $S$. aureus especially ica $A$, icaD, pvl and tst and the grading or the severity of the diabetic foot ulcers when 95 diabetic patients with diabetic foot infections were studied. This conclusion needs to be supported by further studies over larger number of cases especially in our locality.

\section{ETHICAL APPROVAL}

Our study protocol was accepted by our research board and ethical committee in Mansoura faculty of Medicine under the code number of: $\mathrm{R} / 16.12 .42$. A written informed consent was obtained from all included cases.

\section{COMPETING INTERESTS}

Authors have declared that no competing interests exist.

\section{REFERENCES}

1. Bakker K, Van Houtum WH, Riley PC. The international diabetes federation focuses on the diabetic foot. Curr. Diab. Rep. 2005;5:436-440.

DOI: $10.1007 / \mathrm{s} 11892-005-0051-y$

2. Singh N, Armstrong DG, Lipsky BA. Preventing foot ulcers in patients with diabetes. J. Am. Med. Ass. 2005;293:217228.

DOI: 10.1001/jama.293.2.217
3. Turhan V, Mutluoglu M, Acar A, Hatipoglu M, Onem Y, Uzun G, et al. Increasing incidence of Gram-negative organisms in bacterial agents isolated from diabetic foot ulcers. J. Infect. Dev. Ctries. 2015;15: 707-712.

DOI: $10.3855 / \mathrm{jidc} .2967$

4. Ozer B, Kalaci A, Semerci E, Duran N, Davul S, Yanat AN. Infections and aerobic bacterial pathogens in diabetic foot. Afr. J. Microbiol. Res. 2010;4:2153-2160.

5. Dowd SE, Wolcott RD, Sun Y, McKeehan $T$, Smith E, Rhoads D. Polymicrobial nature of chronic diabetic foot ulcer biofilm infections determined using bacterial tag encoded FLX amplicon pyrosequencing (bTEFAP). PLoS ONE. 2008;3:e3326. DOI: 10.1371/journal.pone.0003326

6. Harastani HH, Araj GF, Tokajian ST. Molecular characteristics of Staphylococcus aureus isolated from a major hospital in Lebanon. Int J Infect Dis. 2014;19:33-8.

DOI: 10.1016/j.ijid.2013.10.007

7. Sekhar S, Ohri M, Chakraborti A. Biofilms: An evolving and universal evasive strategy of bacterial pathogens. In: Mendez-Vilas A, editor. Current Research, Technology and Education Topics in Applied Microbiology and Microbial BioTechnology. Badajoz, Spain: Formatex. 2010;855-859.

8. Gordon RJ, Lowy FD. Pathogenesis of methicillin-resistant Staphylococcus aureus infection. Clin Infect Dis. 2008;46(Suppl 5): S350-9.

DOI: $10.1086 / 533591$

9. Chambers HF, Deleo FR. Waves of Resistance: Staphylococcus aureus in the Antibiotic Era. Nat Rev Microbiol. 2010; 7:629-41.

DOI: $10.1038 / \mathrm{nrmicro} 2200$

10. Holmes A, Ganner M, McGuane S, Pitt TL, Cookson BD, Kearns AM. Staphylococcus aureus isolates carrying Panton-valentine leucocidin genes in England and Wales: Frequency, characterization, and association with clinical disease. J Clin Microbiol. 2005;43:2384-90.

DOI: 10.1128/JCM.43.5.2384-2390.2005

11. Durand G, Bes M, Meugnier H. New methicillin-resistant Staphylococcus aureus clones containing the toxic shock syndrome toxin 1 gene responsible for hospital-and community-acquired infections. J Clin Microbiol. 2006;44:84753.

DOI: 10.1128/JCM.44.3.847-853.2006 
12. Nhan TX, Leclercq $\mathrm{R}$, Cattoir V. Prevalence of toxin genes in consecutive clinical isolates of Staphylococcus aureus and clinical impact. Eur. J. Clin. Microbiol. Infect. Dis. 2011;30:719-725.

DOI: $10.1007 / \mathrm{s} 10096-010-1143-4$

13. Wilson MJ, Weightman AJ, Wade WG. Applications of molecular ecology in the characterization of uncultured microorganisms associated with human disease. Rev. Med. Microbiol. 1997;8:91102.

14. Nelson EA, Wright-Hughes A, Brown S, Lipsky BA, Backhouse M, Bhogal M, Ndosi M, Reynolds C, Sykes G, Dowson C, Edmonds M, Vowden $\mathrm{P}$, Jude EB, Dickie $\mathrm{T}$, Nixon J. Concordance in diabetic foot ulceration: A cross-sectional study of agreement between wound swabbing and tissue sampling in infected ulcers Journal: Health Technology Assessment. 2016;20: 82.

15. Wagner FW. The dysvascular foot: A system for diagnosis and treatment. Foot Ankle. 1981;2:64-122.

16. Kimberley C, Elsa B. Identification of Bacterial Species. Association for Biology Laboratory Education (ABLE); 2003. Available:http://www.zoo.utoronto.ca/able

17. Arciola CR, Baldassarri L, Montanaro L. Presence of icaA and icaD genes and slime production in a collection of staphylococcal strains from catheterassociated infections. J Clin Microbiol. 2001;39:2151-6.

DOI: 10.1128/JCM.39.6.2151-2156.2001

18. Akineden Ö, Annemüller $\mathrm{C}$, Hassan $\mathrm{AA}$, Lämmler C, Zschöck M, Annemu C. Toxin genes and other characteristics of Staphylococcus aureus isolates from milk of cows with Mastitis. Society. 2001;8:959_ 64.

19. Lina G, Piemont $\mathrm{Y}$, Bes F, Prter M, Gauduchon V. Vandenesh F, Etienne J. Involvement of Panton-valentine Leukocidin-producing Staphylococcus aureus in primary skin infections and pneumonia. Clin Infect Dis. 1999;29(5): 1128-1132.

DOI: $10.1086 / 313461$

20. Jarraud S, Cozon G, Vandenesch F, Bes $M$, Etienne J, Lina $G$. Involvement of enterotoxins $G$ and I in staphylococcal toxic shock syndrome and staphylococcal scarlet fever. J. Clin. Microbiol. 1999;37: 2446.
21. Richard JL, Lavigne JP, Got I, et al. Management of patients hospitalized for diabetic foot infection: Results of the French OPIDIA study. Diabetes Metab. 2011;37:208-215.

22. Sotto A, Lina G, Richard JL, et al. Virulence potential of Staphylococcus aureus strains isolated from diabetic foot ulcers: A new paradigm. Diabetes Care. 2008;31:2318-2324.

23. Messad N, Prajsnar TK, Lina G, O'Callaghan D, Foster SJ, Renshaw SA, Skaar EP, Bes M, Dunyach-Remy C, Vandenesch F, Sotto A, Lavigne JP. Existence of a Colonizing Staphylococcus aureus strain isolated in diabetic foot ulcers. Diabetes. 2015;64(8):2991-5.

24. Belefquih $B$, Frikh $M$, Benlahlou $Y$, Maleh $A$, Jadid $L$, Bssaibis $F$, Ghazouani $M$, Chagar B, Lamsaouri J, Lemnouer A, Elouennass M. Diabetic foot infection in Morocco: Microbiological profile. Wounds. 2016;28(3):89-98.

25. Lipsky BA, Berendt AR, Cornia PB, Pile JC, Peters EJ, Armstrong DG, Deery HG, Embil JM, Joseph WS, Karchmer AW, Pinzur MS, Senneville E. Infectious Diseases Society of America: Infectious Diseases Society of America clinical practice guideline for the diagnosis and treatment of diabetic foot infections. Clin Infect Dis. 2012;:e132-e173.

26. Citron DM, Goldstein EJ, Merriam CV, Lipsky BA, Abramson MA. Bacteriology of moderate-to-severe diabetic foot infections and in vitro activity of antimicrobial agents. J Clin Microbiol. 2007;45:2819-2828.

27. Roberts AD, Simon GL. Diabetic foot infections: The role of microbiology and antibiotic treatment. Semin Vasc Surg. 2012;25:75-81.

28. Gardner SE, Hillis SL, Heilmann K, Segre JA, Grice EA. The neuropathic diabetic foot ulcer microbiome is associated with clinical factors. Diabetes. 2013;62:923930.

29. Sotto A, Richard JL, Jourdan N, Combescure C, Bouziges N, Lavigne JP, Nîmes. University Hospital Working Group on the Diabetic Foot (GP30): Miniaturized oligonucleotide arrays: A new tool for discriminating colonization from infection due to Staphylococcus aureus in diabetic foot ulcers. Diabetes Care. 2007;30:20512056.

30. Sotto A, Richard JL, Messad N, Molinari N, Jourdan N, Schuldiner S, Sultan A, 
Carrière C, Canivet B, Landraud L, Lina G, Lavigne JP, the French study group on the diabetic foot: Distinguishing colonization from infection with Staphylococcus aureus in diabetic foot ulcers with miniaturized oligonucleotide arrays: A French multicenter study. Diabetes Care. 2012; 35:617-623.

31. Mottola C, Matias CS, Mendes JJ, MeloCristino J, Tavares L, Cavaco-Silva P, Oliveira M. Susceptibility patterns of Staphylococcus aureus biofilms in diabetic foot infections. BMC Microbiol. 2016; 16(1):119.

32. Neut D, Tijdens-Creusen EJ, Bulstra SK, van der Mei HC, Busscher HJ. Biofilms in chronic diabetic foot ulcers--a study of 2 cases. Acta Orthop. 2011;82(3):383-5.

33. Kaplan JB. Antibiotic-induced biofilm formation. Int J Artif Organs. 2011;34(9): 737-51.

34. Mottola C, Semedo-Lemsaddek T, Mendes JJ, Melo-Cristino J, Tavares L, CavacoSilva $\mathrm{P}$, Oliveira M. Molecular typing, virulence traits and antimicrobial resistance of diabetic foot staphylococci. J Biomed Sci. 2016;23:33.

35. Stappers $M H$, Hagen $F$, Reimnitz $P$, Mouton JW, Meis JF, Gyssens IC. Direct molecular versus culture-based assessment of Gram-positive cocci in biopsies of patients with major abscesses and diabetic foot infections. Eur J Clin Microbiol Infect Dis. 2015;34(9):188592.

36. Kaneko J, Kamio Y. Bacterial twocomponent and hetero-heptameric poreforming cytolytic toxins: Structures, poreforming mechanism, and organization of the genes. Biosci Biotechnol Biochem. 2004;68(5):981-1003.

37. Shallcross LJ, Fragaszy E, Johnson AM, Hayward AC. The role of the PantonValentine leucocidin toxin in staphylococcal disease: A systematic review and meta-analysis. Lancet Infect Dis. 2013;13(1):43-54.

(c) 2017 Nabiel and Barakat; This is an Open Access article distributed under the terms of the Creative Commons Attribution License (http://creativecommons.org/licenses/by/4.0), which permits unrestricted use, distribution, and reproduction in any medium, provided the original work is properly cited.

Peer-review history:

The peer review history for this paper can be accessed here: http://sciencedomain.org/review-history/19958 